\title{
Renal Glucosyltransferase Activity in Highly-inbred Spontaneously Diabetic Chinese Hamsters
}

\author{
A. Y. Chang, R. E. Noble, C. S. Perry, and H. S. Greenberg \\ Diabetes and Atherosclerosis Research and Biostatistics, The Upjohn Company, Kalamazoo, Michigan, USA
}

Summary. A modified glucosyltransferase assay using degraded gelatin as acceptors was found to be enzyme concentration- and time-dependent in the Chinese hamster kidney extracts. In 54 Chinese hamsters selected from 7 highly inbred sublines with or without spontaneous glycosuria, the glucosyltransferase activity $(0.78-3.25 \mathrm{unit} / \mathrm{g})$ in the kidney was found to be significantly correlated $(P=0.0002)$ to blood sugar concentrations $(60-475 \mathrm{mg} / \mathrm{dl})$. However, subline-dependent variation in glucosyltransferase activity was also evident and, in animals from 2 of the 5 diabetic sublines, similar activity of glucosyltransferase was found in their kidneys as in those of nondiabetic animals. It was concluded that renal glucosyltransferase activity was affected by blood sugar level as well as by genetically determined factor(s).

Key words: Diabetes, Chinese hamsters, kidney, glucosyltransferase, subline.

Increased activity of UDP-glucose: galactosylhydroxylysine-glucosyltransferase (EC 2.4.1.66) has been observed in the kidney cortices of chemicallyinduced diabetic rats $[1,2]$ and genetically prediabetic mice [3] and it was postulated to be one of the biochemical bases of diabetic microangiopathy. The subject remains controversial, however, since experimental evidence suggesting the contrary has also been reported [4, 5]. A study on kidney glucosyltransferase activity in the highly inbred Chinese hamsters with spontaneous diabetes was thus carried out. This colony of diabetic animals was noted for its genetic mosaicism [6-8] in addition to its welldefined diabetic syndrome [9]. Furthermore, renal glomerulosclerosis has been documented in the Chinese hamsters with prolonged hyperglycaemia [10]. The present investigation employed the convenient assay system for glucosyltransferase using partially degraded gelatin as glucose-acceptor [11]. To verify the specificity of this assay for the Chinese hamster kidney enzyme, studies on time- and enzymedependence and analysis of the reaction products were also carried out.

\section{Materials and Methods}

\section{Animals}

The Chinese hamsters were all males, 12-13.7 months old and derived from 7 highly inbred sublines, the origin of which was described previously [7]. Animals from the diabetic sublines OT, AC, X, XA, and $\mathrm{AH}$ showed $3+$ or $4+$ glycosuria on Testape ${ }^{\circledR}$. All studies were initiated between 8 and $9 \mathrm{a}$. m. After exsanguination through orbital sinus, the animals were decapitated and the kidneys were quickly excised and rinsed in ice-cold $0.154 \mathrm{~mol} / \mathrm{l}$ saline. The whole kidneys, dissected cortices, or medullae were homogenized in a Polytron ${ }^{\circledR}$ apparatus at a setting of 5 for $30 \mathrm{sec}$ twice with a $30 \mathrm{sec}$ cooling in ice in between in a buffer ( $\mathrm{pH}$ 6.8) containing $0.15 \mathrm{~mol} / 1$ Tris-acetate, $2 \mathrm{mmol} / 12$-mercaptoethanol, $0.25 \%(\mathrm{v} / \mathrm{v})$ Triton $\times 100$ [11]. After stirring for $60 \mathrm{~min}$ in ice, the mixture was centrifuged at $100000 \times \mathrm{g}$ for one hour. The supernatant was saved and solid Carbowax ${ }^{\circledR} 6000$ (Union Carbide) was added to a final concentration of $7 \%(\mathrm{w} / \mathrm{v})$. After stirring for $15 \mathrm{~min}$ in ice, the suspension was centrifuged at $30000 \times \mathrm{g}$ for $20 \mathrm{~min}$ and the precipitate was dissolved in $0.5 \mathrm{ml}$ of the abovementioned buffer and kept frozen at $-20^{\circ} \mathrm{C}$ for 1 to 10 days until use. No significant loss of activity was evident during storage.

\section{Assays}

Glucosyltransferase was assayed with slight modifications by the method described by Draeger and Weithmann [11]. The reaction mixture contained $75 \mu \mathrm{mol}$ tris-acetate, $\mathrm{pH} 6.5,10 \mu \mathrm{mol}$ sodium chloride, $20 \mathrm{mg}$ partially degraded gelatin (a gift from Dr. Draeger $)$, and $33.3 \mathrm{nmol}$ UDP-glucose- ${ }^{14} \mathrm{C}(15 \mu \mathrm{Ci} / \mu \mathrm{mol})$ in a 


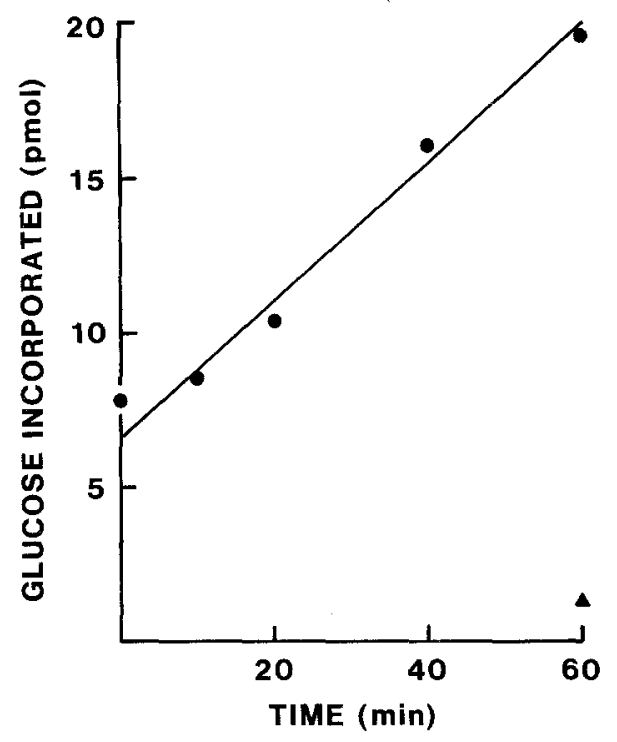

Fig. 1. Effect of time on the incorporation of glucose into degraded gelatin with glucosyltransferase in the Chinese hamster kidney (-) $\Delta$ represents radioactivity found in the washed reaction products without the presence of degraded gelatin in the reaction mixture

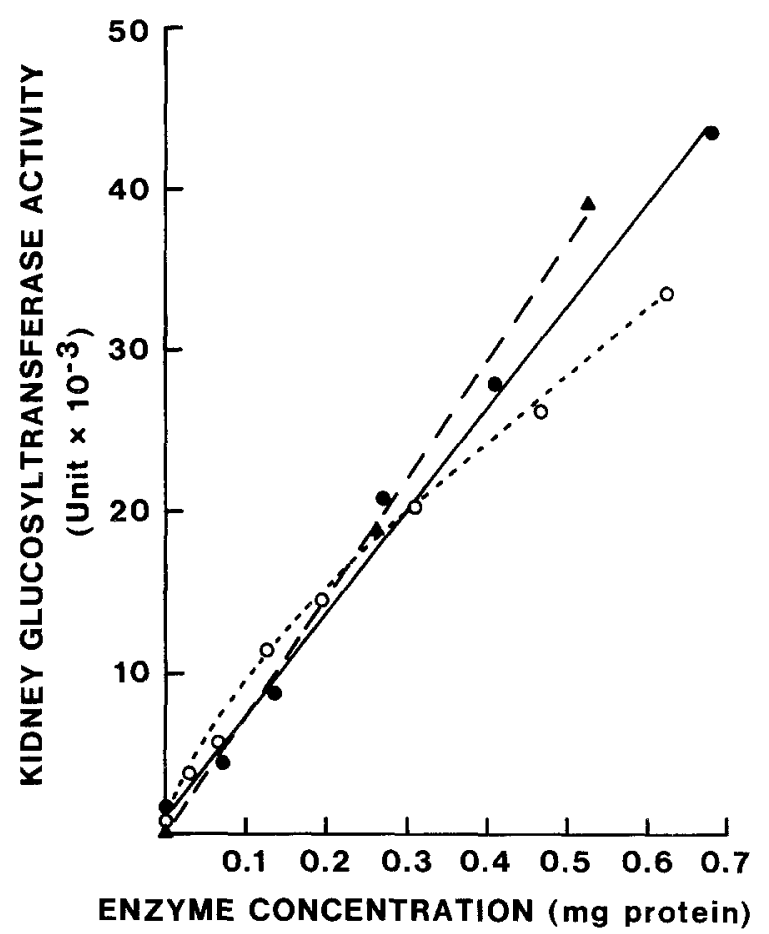

Fig. 2. Effect of enzyme concentration on Chinese hamster glucosyltransferase activity in the whole kidney $(-\bullet)$, cortex $(\boldsymbol{\Delta}--\mathbf{\Delta})$, and medulla $(\mathrm{O} \cdots$.$) . Incubation was carried out$ for $60 \mathrm{~min}$ volume of $0.5 \mathrm{ml}$. The reaction was started by adding $0.05 \mathrm{ml}$ enzyme solution and allowed to proceed at $37^{\circ} \mathrm{C}$ for $60 \mathrm{~min}$. The incubations were stopped by adding $0.5 \mathrm{ml}$ ice-cold $2 \%(\mathrm{w} / \mathrm{v})$ phosphotungstic acid $-1.0 \mathrm{~mol} / 1$ hydrochloric acid. One $\mathrm{ml} 1 \%$ $(\mathrm{w} / \mathrm{v}$ ) phosphotungstic acid $-0.5 \mathrm{~mol} / \mathrm{l} \mathrm{HCl}$ was then added. The precipitates were washed 4 times with $2 \mathrm{ml}$ cold $16 \%(\mathrm{w} / \mathrm{v})$ trichloracetic acid, dissolved in $1 \mathrm{ml} \mathrm{NCS}$-tissue solubilizer (Amersham Corp.), and counted in $15 \mathrm{ml}$ Bray solution [12] in a scintillation counter. Counts of zero time controls were subtracted from those of $60 \mathrm{~min}$ incubation. One unit of enzyme was defined as the incorporation of $1 \mathrm{nmol}$ glucose into the acceptor in $60 \mathrm{~min}$.

To analyze the reaction products [2], the trichloroacetic acidwashed precipitates were hydrolyzed in $0.5 \mathrm{ml} 2 \mathrm{~mol} / 1$ sodium hydroxide at $105^{\circ} \mathrm{C}$ for 20 hours. After the addition of $2.5 \mathrm{ml}$ water, the mixture was adjusted to $\mathrm{pH} 3$ with $1 \mathrm{~mol} / 1$ hydrochloric acid and allowed to stand in the cold room overnight. The precipitates were collected and the supernatant was passed through a $0.7 \times$ $9 \mathrm{~cm}$ column of Dowex $50 \mathrm{~W}-\mathrm{X} 4\left(\mathrm{H}^{+}\right), 200-400$ mesh in water and washed with $60 \mathrm{ml}$ water. The eluate was lyophilized and designated as " $\mathrm{H}_{2} \mathrm{O}$ eluate". The column was then eluted with $15 \mathrm{ml} 1.5 \mathrm{~mol} / 1$ ammonium hydroxide and the eluate was also lyophilized. The precipitates and the lyophilized " $\mathrm{H}_{2} \mathrm{O}$ " and "ammonium hydroxide" eluates were suspended in $1 \mathrm{ml}$ water and measured for radioactivity in $15 \mathrm{ml}$ Bray solution in a scintillation counter [12].

Blood sugar in samples collected at the time of exsanguination was determined by the ferricyanide method [13] and protein by a modified Lowry procedure [14]

\section{Statistical Methods [15]}

For each variable listed in Table 3, a one-way analysis of variance was used to test for overall subline-dependent differences. In cases of significant endpoints, Duncan's Multiple Range Test was used

Table 1. Effects of cofactors on kidney glucosyltransferase activity

\begin{tabular}{llr}
\hline Incubation mixture & unit/mg protein & $\%$ \\
\hline Complete & 0.073 & 100 \\
-Manganese acetate & 0.005 & 7 \\
-Sodium chloride & 0.084 & 115 \\
-2-Mercaptoethanol & 0.065 & 89 \\
-Enzyme & 0.000 & 0
\end{tabular}

Incubation was carried out at $37^{\circ} \mathrm{C}$ for $60 \mathrm{~min}$ with $0.5 \mathrm{mg}$ enzyme proteins

Table 2. Analysis of alkaline hydrolysates in trichloroacetic acidwashed reaction products on Dowex $50\left(\mathrm{H}^{+}\right)$column

\begin{tabular}{lrr}
\hline & \multicolumn{2}{c}{ Radioactivity } \\
\cline { 2 - 3 } Fractions & \multicolumn{1}{c}{ DPM } & \multicolumn{1}{c}{$\%$ Total } \\
\hline Precipitates & $72 \pm 26$ & $4.2 \pm 1.6$ \\
$\mathrm{H}_{2} \mathrm{O}$ eluate $1.5 \mathrm{~mol} / \mathrm{l}$ & $291 \pm 27$ & $16.6 \pm 1.0$ \\
Ammonium hydroxide eluate & $1388 \pm 55$ & $79.3 \pm 0.7$ \\
\hline
\end{tabular}

Incubations and sample treatments are described in Materials and Methods. Numbers given are the averages of two experiments 
Table 3. Kidney glucosyltransferase activity and other variables in the Chinese hamsters from seven highly inbred sublines

\begin{tabular}{|c|c|c|c|c|c|c|c|}
\hline \multirow[b]{2}{*}{ Variables } & \multicolumn{7}{|c|}{ Sublines (Mean $\pm \mathrm{SEM}) *$} \\
\hline & $\mathbf{M}$ & AV & OT & $\mathrm{AC}$ & $\mathrm{X}$ & XA & $\mathrm{AH}$ \\
\hline Blood sugar $(\mathrm{mg} / 100 \mathrm{ml})$ & $83 \pm 2^{b}$ & $85 \pm 9^{b}$ & $183 \pm 30^{d}$ & $269 \pm 27^{\mathrm{a}, \mathrm{c}}$ & $270 \pm 24^{a}$ & $351 \pm 34^{\mathrm{a}}$ & $366 \pm 43^{\mathrm{a}}$ \\
\hline Age (months) & $13.4 \pm 0.7$ & $13.1 \pm 0.2$ & $13.1 \pm 0.1$ & $13.3 \pm 0.2$ & $13.4 \pm 0.8$ & $12.9 \pm 0.3$ & $13.3 \pm 0.5$ \\
\hline Duration of glycosuria (months) & - & - & $9.3 \pm 1.4$ & $11.0 \pm 0.2$ & $10.9 \pm 1.0$ & $11.5 \pm 0.4$ & $11.5 \pm 0.7$ \\
\hline Body weight (g) & $34.1 \pm 0.9^{b, c}$ & $34.5 \pm 1.0^{\mathrm{b}, \mathrm{c}}$ & $34.4 \pm 1.7^{\mathrm{b}, \mathrm{c}}$ & $33.0 \pm 0.9^{b, c}$ & $31.6 \pm 0.8^{c}$ & $35.1 \pm 0.8^{b}$ & $39.4 \pm 0.7^{\mathrm{a}}$ \\
\hline Kidney weight (g) & $0.32 \pm 0.01^{\mathrm{e}}$ & $0.36 \pm 0.01^{\mathrm{d}, \mathrm{e}}$ & ${ }^{\mathrm{e}} 0.38 \pm 0.02^{\mathrm{c}, \mathrm{d}}$ & ${ }^{d} 0.43 \pm 0.02^{b, c}$ & ${ }^{\mathrm{c}} 0.45 \pm 0.03^{\mathrm{b}}$ & $0.44 \pm 0.02^{\mathrm{b}}$ & $0.53 \pm 0.01^{\mathrm{a}}$ \\
\hline $\begin{array}{l}\text { Protein concentration in } \\
\text { glucosyltransferase } \\
\text { preparation ( } \mathrm{mg} / \mathrm{g} \text { tissue) }\end{array}$ & $18.1 \pm 1.4^{\mathrm{a}}$ & $18.6 \pm 1.5^{\mathrm{a}}$ & $18.7 \pm 1.8^{\mathrm{a}}$ & $18.1 \pm 1.8^{\mathrm{a}}$ & $21.1 \pm 2.0^{\mathrm{a}}$ & $17.4 \pm 2.3^{\mathrm{a}}$ & $18.9 \pm 2.0^{\mathrm{a}}$ \\
\hline $\begin{array}{l}\text { Glucosyltransferase } \\
\text { (U/g tissue) }\end{array}$ & $1.32 \pm 0.10^{\mathfrak{c}}$ & $1.58 \pm 0.09^{b, c}$ & ${ }^{c} 1.32 \pm 0.09^{c}$ & $1.28 \pm 0.13^{\mathrm{c}}$ & $2.02 \pm 0.14^{b}$ & $1.86 \pm 0.17^{\mathrm{b}}$ & $2.50 \pm 0.26^{\mathrm{a}}$ \\
\hline $\begin{array}{l}\text { Glucosyltransferase } \\
\left(\mathrm{U} \times 10^{-3} / \mathrm{mg} \text { protein }\right)\end{array}$ & $77 \pm 9^{\mathrm{b}, \mathrm{c}}$ & $89 \pm 9^{b, c}$ & $72 \pm 5^{\mathrm{b}, \mathrm{c}}$ & $74 \pm 9^{c}$ & $103 \pm 16^{\mathrm{b}, \mathrm{c}}$ & $117 \pm 16^{a, b}$ & $144 \pm 21^{a}$ \\
\hline
\end{tabular}

* Means superscripted with the same letter are not significantly different at $\mathrm{P}<0.05$ whereas superscripts in different letters depict that significant difference at $\mathbf{P}<0.05$ was present between the sublines. For example, the blood sugar levels of sublines $M$ and $A V$, both superscripted with the letter $\mathrm{b}$, were not significantly different, whereas they were different from those of sublines OT, AC, X, XA, or AH, superscripted with a, c, or d. There were 8 animals in sublines $\mathrm{M}, \mathrm{AV}, \mathrm{OT}, \mathrm{AC}, \mathrm{AH}$ and 7 in $\mathrm{X}, \mathrm{XA}$

to compare sublines with each other. If a significant heterogeneity of subline variances was present, the nonparametric Kruskal-Wallis Test was used to test for overall subline-dependent differences. In cases of significant endpoints, Wilcoxon Rank-Sum Tests were used to compare the sublines with each other. Data were presented as Means \pm SEM and each subline contained 8 animals except $X$ and XA sublines which had 7 each.

Product moment correlation was computed between blood glucose and glucosyltransferase activity (Fig. 3 ).

\section{Results}

Figure 1 shows the time-dependent incorporation of glucose into the acceptors with glucosyltransferase prepared from a pool of kidneys isolated from Chinese hamsters of several sublines. The incorporation in the absence of added acceptor was negligible after $60 \mathrm{~min}$ incubation. Figure 2 depicts the effect of enzyme concentration on the incorporation. In terms of $\mathrm{mg}$ protein, the glucosyltransferase prepared from either cortex or medulla showed similar specific activity as that from the whole kidney in its ability to transfer glucose from UDP-glucose into degraded gelatin.

Table 1 lists the effects of various cofactors on kidney glucosyltransferase activity. In the absence of $\mathrm{Mn}^{++}$, only $7 \%$ of incorporation was observed whereas there appeared to be little or no requirements for 2-mercaptoethanol or $\mathrm{NaCl}$. Virtually no incorporation was observed when enzyme was omitted. The reaction products were further analyzed by alkaline hydrolysis according to Haft and Reddi [2]. As shown in Table 2, 79\% of the incorporated radioactivity present in the hydrolysate was retained by cation exchange resin and could be eluted off the column by $1.5 \mathrm{~mol} / 1$ ammonium hydroxide. The remaining radioactivity was recovered in the insoluble residues $(4.2 \%)$ and in the fraction not retained on Dowex 50 column (16.6\%).

Table 3 summarizes the study on kidney glucosyltransferase activity in the Chinese hamsters selected from 7 different sublines, 4 of which contained diabetic animals with varying degree of hyperglycemia. Although they were similar in age, the AH subline produced heavier animals than the others and the diabetic Chinese hamsters tended to have larger kidneys than the nondiabetics. The amount of proteins recovered in the partially purified enzyme solution varied among the sublines, $X$ subline showing the highest and XA subline the lowest protein recovery in the enzyme solution. Glucosyltransferase activity in the kidney, expressed either in terms of unit/g of wet kidney or unit/mg of proteins recovered in the partially purified enzyme solution, was significantly higher in the diabetic $\mathrm{AH}$ subline animals than in the others. The kidneys of the diabetic X and XA subline Chinese hamsters also showed higher collagen glucosyltransferase activity whereas the diabetic animals in OT and AC sublines had similar activity as those in the nondiabetic $M$ and $A V$ sublines (Table 3 ).

Figure 3 shows the relationship between blood sugar level and renal glucosyltransferase activity (unit/g tissue). A significant overall correlation at $\mathrm{P}$ $=0.0002$ level $(\mathrm{r}=0.48)$ was found between these two variables. A similar correlation of $r=0.36$, $\mathrm{P}=0.007$, was also observed between blood sugar 


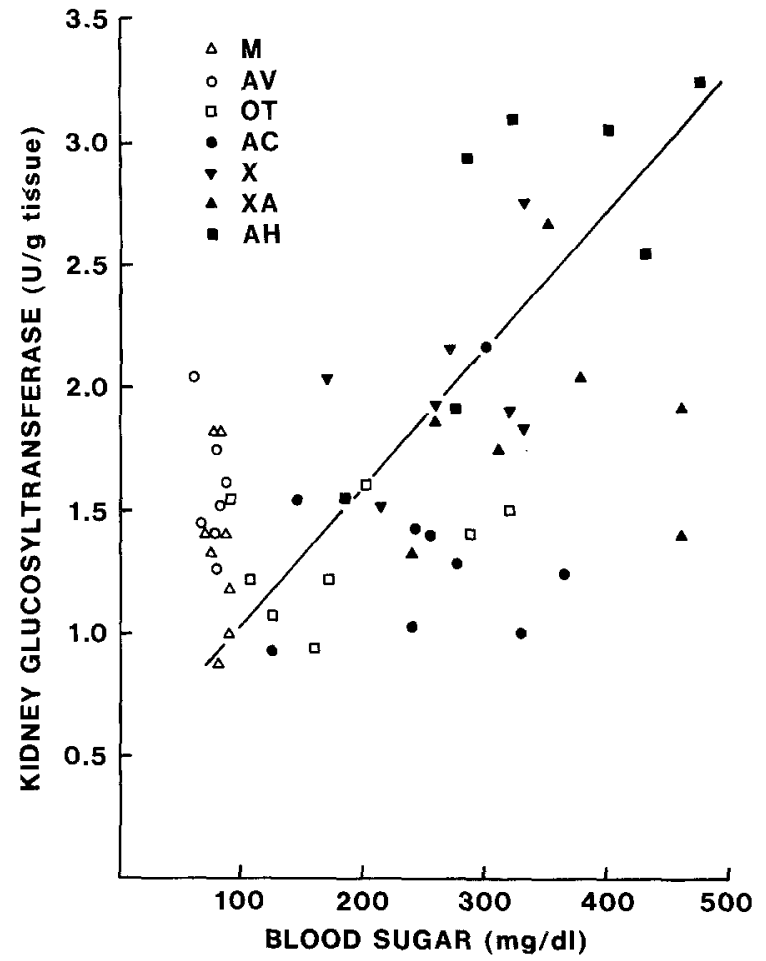

Fig. 3. Correlation between blood sugar level and kidney glucosyltransferase activity in normal and spontaneously diabetic Chinese hamsters. $\mathrm{r}=0.48$ and $\mathrm{P}=0.0002$

concentration and glucosyltransferase activity expressed as unit/mg protein. When the data are examined within each subline, it is evident that the diabetic animals with higher blood sugar in sublines $\mathrm{AH}, \mathrm{XA}$, and $\mathrm{X}$ also tended to show more kidney glucosyltransferase activity than those with lower blood sugar in the same subline. However, sublinespecific factors also played important roles in regulating kidney glucosyltransferase activity since the hyperglycaemic animals in $\mathrm{AC}$ and $\mathrm{OT}$ sublines showed similar glucosyltransferase activity as the nondiabetic $\mathrm{M}$ and $\mathrm{AV}$ subline animals.

\section{Discussion}

The purpose of this study was to investigate the correlation between hyperglycaemia and kidney glucosyltransferase activity in the highly inbred Chinese hamsters with spontaneous diabetes since the significance of this enzyme in the development of diabetic nephropathy $[1-3]$ remains controversial $[4$, 5]. The assay employed was the convenient procedure devised by Draeger and Weithmann [11] using degraded gelatin as acceptor for glucose. Our data confirmed the specificity of the assay since $79 \%$ of the incorporated radioactivity recovered in the alkaline hydrolysate of the reaction products was retained by cation exchange resins [2]. Therefore, the degraded gelatins appeared to serve as adequate substrates for UDP-glucose: galactosylhydroxylysine glucosyltransferase. The enzymes isolated from either cortex or medulla showed similar specific activity, in terms of unit/mg proteins, as that from the whole kidney in the Chinese hamsters. It was difficult to compare our data to those found by Haft and Reddi in the rat [2] due to differences in animal species, methods of enzyme fractionation, and substrates used in the enzyme assay. In subsequent studies, it was decided to use whole kidney as the source of enzyme.

Our findings showed significant correlation between the degree of hyperglycaemia and renal glucosyltransferase activity in diabetic Chinese hamsters from some sublines but other unknown genetic determinants appeared to play additional roles in regulating the activity of this enzyme in the Chinese hamster kidney. It is notable that one of the sublines, i. e., AC, which contained diabetic animals with essentially normal kidney glucosyltransferase activity, also showed anomalies in other diabetes-related changes. Specifically, diabetic Chinese hamsters from most sublines showed depression of renal $\alpha$-D-galactosidase (EC 3.2.1.22) and $\beta$-D-galactosidase (EC 3.2.1.23) levels [7] and elevation of plasma $\mathrm{N}$-acetyl$\beta$-D-glucosaminidase (EC 3.2.1.30) [8] whereas the diabetic Chinese hamsters in the AC subline exhibited similar levels of these enzymes as the nondiabetics. Most importantly, the AC subline diabetic animals also showed thinner renal glomerulus capillary basement membranes than the diabetic animals from other sublines with similar degree of hyperglycaemia [16]. Therefore, predisposed genetic factors are likely to play roles in the various forms of diabetic complications and this may offer an explanation for the lack of uniformity in the occurrence of complications of diabetic patients.

\section{References}

1. Spiro RG, Spiro MJ (1971) Effect of diabetes on the biosynthesis of the renal glomerular basement membrane, studies on the glucosyltransferase. Diabetes 20;641-648

2. Haft DE, Reddi AS (1979) Glucosyltransferase activity in kidney fractions of normal and streptozotocin-diabetic rats. Biochim Biophys Acta 584: 1-10

3. Reddi AS, Oppermann W, Reddy MP, Velasco CA, CameriniDavalos RA (1976) Elevated kidney glucosyltransferase activity in genetic prediabetic mice. Experientia 32: 1237-1238

4. Risteli J, Koivisto VA, Akerblom HK, Kivirikko KJ (1976) Intracellular enzymes of collagen biosynthesis in rat kidney in streptozotocin diabetes. Diabetes 25: 1066-1070 
5. Duhault J, Lonchampt M (1977) Glucosyltransferase activity and diabetic microangiopathy. Biomedicine 27: 127-131

6. Chang AY, Noble RE, Greenberg HS (1977) Variance in LDH isozyme patterns in a Chinese hamster (Cricetulus griseus) colony. Comp Biochem Physiol [B] 58: 119-123

7. Chang AY, Greenberg HS (1978) Acid glycohydrolase in Chinese hamsters with spontaneous diabetes. III. Line-dependent variance. Biochim Biophys Acta 525: 134-141

8. Chang AY, Perry CS (1978) Acid glycohydrolase in Chinese hamsters with spontaneous diabetes. IV. Diabetes and linedependent variance in plasma enzyme activities. Diabetologia 15: 423-429

9. Gerritsen GC, Dulin WE (1967) Characterization of diabetes in the Chinese hamster. Diabetologia 3: 74-84

10. Soret MG, Dulin WE, Gerritsen GC (1973) Microangiopathy in animals with spontaneous diabetes. In: Camerini-Dávalos R, Cole HS (eds) Early diabetes. Supplement II to Advances in metabolic disorders. Academic Press, New York, p 291-298

11. Draeger KE, Weithmann KU (1978) A modified assay system for collagen glucosyltransferase. Diabetologia 15: 125-128

12. Bray GA (1960) A simple efficient liquid scintillator for counting aqueous solutions in a liquid scintillator counter. Anal Biochem 1: 279-285
13. Gerritsen GC, Dulin WE (1965) Effect of a new hypoglycemic agent, 3,5-dimethylpyrazole, on carbohydrate and free fatty acid metabolism. Diabetes 14: 507-515

14. Markwell MAK, Haas SM, Bieber LL, Tolbert NE (1978) A modification of the Lowry procedure to simplify protein determination in membrane and lipoprotein samples. Anal Biochem 87: 206-210

15. Snedecor GW, Cochran WG (1967) Statistical methods. Iowa State University Press, Ames, IA, p 130-132 (Non-parametric methods), p 172-188 (Correlation), p 258-274 (One-way Anovai)

16. Soret MG, Peterson T, Block EM, Chang AY (1978) Glomerular capillary basement membrane thickening in spontaneously diabetic Chinese hamsters. Diabetes 27 [Suppl 2]: 446

Received: June 8, 1979

and in revised form: January 30, 1980

Dr. A. Y. Chang

Diabetes and Atherosclerosis Research

The Upjohn Company

Kalamazoo, MI 49001

USA 